\title{
The Measurement of Member Satisfaction Level Toward Koperasi Ships Jawa Timur Service
}

\author{
Renanda Nia Rachmadita*, Putri Rahmatul Isti'anah, \\ Nur Fitriana Arumita \\ Business Management \\ Shipbuilding Institute of Polytechnic Surabaya \\ Surabaya, Indonesia \\ *nia.renanda@gmail.com, putri.rahmatul.putri@gmail.com, \\ arumita028@gmail.com
}

\author{
Nurvita Arumsari \\ Marine Engineering \\ Shipbuilding Institute of Polytechnic Surabaya \\ Surabaya, Indonesia \\ arum.up3d@gmail.com
}

\author{
Imam Mahfudzi \\ Health and Safety Engineering \\ Shipbuilding Institute of Polytechnic Surabaya \\ imammahfudzi@gmail.com
}

\begin{abstract}
The purpose of this study are to determine the extent of the gap between expectations and perceptions of Koperasi SHIPS Jawa Timur (KSJ) members, in this case KSJ is a Cooperative that both established and run using the Islamic Sharia. Besides, it aims to identify the service quality attributes that need to be considered in order to improve the quality of KSJ services. Questionnaire distribution was carried out based on the CARTER's dimensions (Compliance, Assurance, Reliability, Tangibles, Empathy, and Responsiveness). It was addressed to the KSJ members both employees and lecturers, resulting 67 respondents to be participated. Reliability and validity tests were conducted to validate the key constructs. The results indicated that the services provided to the KSJ members were still below the respondents' expectations. The biggest gap value was $\mathbf{- 1 . 6 7}$ in item P15 (Attractive appearance of the KSJ office and physical facilities). This means that the appearance of the office and supporting equipment of the KSJ was very much needed by the respondents, but in reality the KSJ has not been able to provide the appearance of the KSJ office in accordance with the respondents 'wishes and is still far from respondents' expectation.
\end{abstract}

Keywords: CARTER, gap analysis, satisfaction level

\section{INTRODUCTION}

Cooperatives have long been recognized to play important roles in society that translate into the improvement of living conditions of their members, particularly the low-income earning cadres of the population; the rural people and the urban poor [1]. Cooperative is a business entity consisting of people or legal entity as people's economic movement based on kinship principle [2]. It is owned by users who are customers. These users are also members, in general, and because they derive the benefits of membership, they are also called patrons because the economic benefits derived from the business done by them as a customer of the cooperative-referred to as patronage - are distributed proportionately based on that patronage [3].

The existence of cooperatives is generally understood as a voluntary association of people who unite themselves to fight for the improvement of economic welfare member, through the establishment of a business entity that is managed democratically [4]. Cooperatives exist to provide benefits to members through their active participation in the cooperative's activities [5]. Good and effective governance help to enhance the financial performance and sustainability of the cooperatives [6].

Sharia cooperatives better known as KJKS (Sharia Financial Services Cooperatives/Koperasi Jasa Keuangan Syariah) and UJKS (Sharia Financial Services Units/Unit Jasa Keuangan Syariah) appeared as the fertile ground for growth and develop in the midst of the Muslim societies' development that are starting to realize and need management of shariabased economic systems, also amid the sluggishness of the conventional cooperatives [7]. KJKS as a cooperative institution is a joint venture that has a function as an instrument of economic struggle, an educational tool, business efficiency, and member independence [8]. The aim of the Sharia Cooperative is to increase the welfare of members in particular and society in general, also to contribute in building an equitable economic order in accordance with Islamic principles [7]. The principle of Sharia Cooperative business is based on the concept of mutual cooperation and is not monopolized by one of the capital owners. Likewise in terms of the profits and losses suffered must be shared equally and proportionally [8].

Today's business company has known that customer satisfaction is the key component for the success of the business and at the same time it plays a vital role to expand the market value [9]. Service quality and customer satisfaction is a very important concept that cooperatives must understand if they want to stay competitive and grow [2]. Members' 
satisfaction is recognized as an important measure to ensure the business success. The goal is to meet the objectives through services offered [10]. Satisfaction means to feel content after what the person desired or wanted [9]. Fulfilling customer anticipations is the major aim for all service oriented organization [11].

Koperasi SHIPS Jawa Timur (KSJ) is a form of cooperative which implement sharia principles. KSJ was established in 2016 with the aim of prospering its members which consist of the academic community at Politeknik Perkapalan Negeri Surabaya (PPNS). In addition, the KSJ is also a form of service sector business that needs to prioritize the members' satisfaction.

Research on service quality had been carried out in various fields, including: Rachmadita and Arninputranto measured the level of service satisfaction provided by libraries in vocational colleges using the Importance-Performance Analysis method based on 5 (five) dimensions of SERVQUAL [12]. Parani et al. analyzed the effect of service quality and performance of cooperatives on the cooperative image and its impact to the satisfaction of cooperative member in Central Sulawesi Province [13]. Thoomkuzhy and John analyzed the quality of services and strategies to enhance the quality of services among Idukki District Cooperative Bank [14].

Based on the explanation above, this research aims to find out the extent of the gap between member expectations and perceptions of Koperasi SHIPS Jawa Timur (KSJ), also to identify the service quality attributes that need to be considered in order to improve the quality of KSJ services.

\section{RESEARCH METHODOLOGY}

The study was done by conducting a survey on the effect of services on the satisfaction of Koperasi Ships Jawa Timur (KSJ) members. Based on the number of KSJ members registered up to January 2019 there were 161 people. The sample calculation in this study uses the Slovin formula. Thus, the minimum number of samples needed in this study with an error of $10 \%$ can be calculated as follows:

$$
n=\frac{161}{1+(161) * 0,1^{2}}=\frac{161}{2.61}=61.69 \approx 62 \text { People }
$$

Thus, in this study there were 67 members who participated as respondents. The attributes to be examined in this study was refer to the dimensions that are often used in evaluating the quality of Islamic banking services are CARTER: Compliance fully with Islamic law and principles, Assurance, Reliability, Tangible, Empathy, and Responsiveness. The distribution of questionnaires was addressed to the KSJ members both employees and lecturers: where the questionnaire consisted of general data, an assessment of the perceptions and expectations of the members. Perception is a performance assessment of KSJ services according to members, while expectations are the extent to which members want the services provided by the KSJ. This research also tested the validity and reliability of the questionnaire, which the test results then will be used to analyze the gap between KSJ members' perceptions and expectations.

\section{RESULTS AND DISCUSSION}

Questionnaires were given to respondents to fill in order to find out the extent of service attributes given to KSJ members. The service attributes used in this study were based on 6 (six) CARTER dimensions, namely Compliance, Assurance, Reliability, Tangible, Empathy, and Responsiveness. This can be seen in the following Table 1:

TABLE I. QUESTIONNAIRE ATTRIBUTES

\begin{tabular}{|c|c|c|}
\hline Dimension & Question Attributes & Code \\
\hline \multirow{4}{*}{ Compliance } & KSJ carries out Islamic principles and law & $\mathrm{P} 1$ \\
\hline & $\begin{array}{l}\text { There is no interest payment on financial } \\
\text { services types at KSJ }\end{array}$ & $\mathrm{P} 2$ \\
\hline & $\begin{array}{l}\text { KSJ applies Islamic product service } \\
\text { provisions }\end{array}$ & P3 \\
\hline & $\begin{array}{l}\text { KSJ provides an opportunity to get an } \\
\text { interest-free loan }\end{array}$ & P4 \\
\hline \multirow{5}{*}{ Assurance } & KSJ employees are polite and friendly & P5 \\
\hline & KSJ provides financial advice/suggestions & P6 \\
\hline & $\begin{array}{l}\text { KSJ has a comfortable office interior and } \\
\text { waiting room }\end{array}$ & P7 \\
\hline & KSJ provides access to account information & P8 \\
\hline & $\begin{array}{l}\text { An experienced and knowledgeable KSJ } \\
\text { management team }\end{array}$ & P9 \\
\hline \multirow{5}{*}{ Reliability } & $\begin{array}{l}\text { KSJ provides pleasant service (fast service } \\
\text { time) }\end{array}$ & $\mathrm{P} 10$ \\
\hline & $\begin{array}{l}\text { KSJ provides extensive products and } \\
\text { services }\end{array}$ & P11 \\
\hline & $\begin{array}{l}\text { KSJ provides security and guarantees in } \\
\text { transactions }\end{array}$ & $\mathrm{P} 12$ \\
\hline & KSJ has optimal service time (hours) & $\mathrm{P} 13$ \\
\hline & $\begin{array}{l}\text { KSJ has integrated use of value added } \\
\text { services }\end{array}$ & $\mathrm{P} 14$ \\
\hline \multirow{5}{*}{ Tangibles } & $\begin{array}{l}\text { Attractive appearance of the KSJ office and } \\
\text { physical facilities }\end{array}$ & $\mathrm{P} 15$ \\
\hline & KSJ provides fast and efficient transactions & $\mathrm{P} 16$ \\
\hline & KSJ has clear operating hours & P17 \\
\hline & $\begin{array}{l}\text { KSJ provides reading material while } \\
\text { members are waiting }\end{array}$ & $\mathrm{P} 18$ \\
\hline & $\begin{array}{l}\text { KSJ provides cash withdrawal services with } \\
\text { privileges }\end{array}$ & P19 \\
\hline \multirow{6}{*}{ Empathy } & Easily accessible location of KSJ & $\mathrm{P} 20$ \\
\hline & $\begin{array}{l}\text { KSJ name, reputation, and image are easily } \\
\text { recognizable }\end{array}$ & $\mathrm{P} 21$ \\
\hline & $\begin{array}{l}\text { KSJ maintains the confidentiality of the } \\
\text { member data }\end{array}$ & $\mathrm{P} 22$ \\
\hline & KSJ management is convincing & $\mathrm{P} 23$ \\
\hline & $\begin{array}{l}\text { KSJ provides profitable products and } \\
\text { services }\end{array}$ & $\mathrm{P} 24$ \\
\hline & KSJ provides a low service tariff & $\mathrm{P} 25$ \\
\hline \multirow{6}{*}{$\begin{array}{l}\text { Responsivenes } \\
\mathrm{S}\end{array}$} & KSJ has financial consultation provisions & $\mathrm{P} 26$ \\
\hline & KSJ employees are willing to help members & P27 \\
\hline & $\begin{array}{l}\text { KSJ employees serve members in Islamic } \\
\text { way }\end{array}$ & $\mathrm{P} 28$ \\
\hline & $\begin{array}{l}\text { KSJ provides loans with a favorable } \\
\text { repayment period }\end{array}$ & $\mathrm{P} 29$ \\
\hline & KSJ provides fast and efficient services & $\mathrm{P} 30$ \\
\hline & KSJ has available and sufficient branches & P31 \\
\hline
\end{tabular}

\section{A. Validity and Reliability Tests}

Validity and reliability tests were conducted by using the SPSS 20.0 software. The results of testing the questionnaire validity for the Perceptions and Expectations section of the respondents could be seen in the Table 2 below: 
TABLE II. QuestionNAIRE VALIDITY TEST RESUlts

\begin{tabular}{|l|l|l|l|l|}
\hline \multirow{2}{*}{ Item } & \multicolumn{2}{|c|}{ Value $\mathbf{r}_{\text {count }}$} & \multirow{2}{*}{$\begin{array}{c}\text { Value } \mathbf{r} \\
\text { table }\end{array}$} & Conclusion \\
\cline { 2 - 4 } & \multicolumn{1}{|c|}{ Perception } & \multicolumn{1}{|c|}{ Expectation } & Valid \\
\hline P1 & 0.537 & 0.823 & 0.24 & Valid \\
\hline P2 & 0.404 & 0.845 & 0.24 & Valid \\
\hline P3 & 0.627 & 0.819 & 0.24 & Valid \\
\hline P4 & 0.538 & 0.74 & 0.24 & Valid \\
\hline P5 & 0.441 & 0.628 & 0.24 & Valid \\
\hline P6 & 0.597 & 0.82 & 0.24 & Valid \\
\hline P7 & 0.657 & 0.818 & 0.24 & Valid \\
\hline P8 & 0.584 & 0.768 & 0.24 & Valid \\
\hline P9 & 0.722 & 0.712 & 0.24 & Valid \\
\hline P10 & 0.763 & 0.816 & 0.24 & Valid \\
\hline P11 & 0.606 & 0.808 & 0.24 & Valid \\
\hline P12 & 0.637 & 0.758 & 0.24 & Valid \\
\hline P13 & 0.638 & 0.865 & 0.24 & Valid \\
\hline P14 & 0.68 & 0.9 & 0.24 & Valid \\
\hline P15 & 0.658 & 0.802 & 0.24 & Valid \\
\hline P16 & 0.789 & 0.874 & 0.24 & Valid \\
\hline P17 & 0.658 & 0.816 & 0.24 & Valid \\
\hline P18 & 0.617 & 0.772 & 0.24 & Valid \\
\hline P19 & 0.716 & 0.803 & 0.24 & Valid \\
\hline P20 & 0.609 & 0.804 & 0.24 & Valid \\
\hline P21 & 0.582 & 0.803 & 0.24 & Valid \\
\hline P22 & 0.666 & 0.769 & 0.24 & Valid \\
\hline P23 & 0.696 & 0.784 & 0.24 & Valid \\
\hline P24 & 0.648 & 0.847 & 0.24 & Valid \\
\hline P25 & 0.728 & 0.849 & 0.24 & Valid \\
\hline P26 & 0.741 & 0.827 & 0.24 & Valid \\
\hline P27 & 0.586 & 0.782 & 0.24 & Valid \\
\hline P28 & 0.654 & 0.764 & 0.24 & Valid \\
\hline P29 & 0.705 & 0.775 & 0.24 & Valid \\
\hline P30 & 0.649 & 0.831 & 0.24 & Valid \\
\hline P31 & 0.534 & 0.693 & 0.24 & Valid \\
\hline & & & & \\
\hline
\end{tabular}

Based on the value of $\mathrm{r}$ table at $\mathrm{n}=67(\mathrm{df}=65)$ and $\alpha=$ 0.05 , the value of 0.24 was obtained and when compared with the calculated value for each question in the section on perception and in the expectation section, the value of $r$ count $>$ $r$ table was obtained, so each item in question was declared valid. By using SPSS 20.0 software, the results of the perception and Expectation reliability questionnaire testing could be seen in Table 3 below:

TABLE III. QUESTIONNAIRE RELIABILITY TEST RESULTS

\begin{tabular}{|l|l|l|l|l|}
\hline Questionnaire & $\begin{array}{c}\text { N } \\
\text { item }\end{array}$ & $\begin{array}{c}\text { Value of } \\
\text { Alpha } \\
\text { Cronbach's }\end{array}$ & $\begin{array}{c}\text { Value } \\
\mathbf{r}_{\text {table }}\end{array}$ & Conclusion \\
\hline Perception & 31 & 0.946 & 0.24 & Reliable \\
\hline Expectation & 31 & 0.980 & 0.24 & Reliable \\
\hline
\end{tabular}

Based on the $r$ table value at $n=67(\mathrm{df}=65)$ and $\alpha=0.05$, the number was 0.24 and when compared with Alpha Cronbach's, it was obtained that Alpha Cronbach's value $>r$ value, so that the questionnaire was declared reliable.

\section{B. Service Quality}

To find out the satisfaction level of the KSJ members, it can be seen whether there is a gap between the services received (perception) and the services expected (expectations) by the KSJ members. The greater the value of the gap between perception and expectation, the lower the level of satisfaction with the quality of service perceived by the KSJ members. Conversely, the smaller the gap between perception and expectation the better the level of satisfaction with the quality of service perceived by the KSJ members. The calculation results of the overall gap average for each dimension could be seen in Table 4 below:

TABLE IV. VAlue Gap BetWeEn Perception AND EXPECTATION

\begin{tabular}{|c|c|c|c|c|}
\hline $\begin{array}{l}\text { Question } \\
\text { Items }\end{array}$ & Perception & Expectation & Gap & $\begin{array}{c}\text { Dimension } \\
\text { Gap }\end{array}$ \\
\hline P1 & 3.99 & 4.52 & -0.53 & \multirow[t]{4}{*}{-0.59} \\
\hline P2 & 3.88 & 4.48 & -0.60 & \\
\hline P3 & 4.04 & 4.57 & -0.53 & \\
\hline P4 & 3.87 & 4.57 & -0.7 & \\
\hline P5 & 4.19 & 4.66 & -0.47 & \multirow[t]{5}{*}{-1.04} \\
\hline P6 & 3.43 & 4.43 & -1 & \\
\hline P7 & 2.79 & 4.40 & -1.61 & \\
\hline P8 & 2.87 & 4.28 & -1.41 & \\
\hline P9 & 3.79 & 4.48 & -0.69 & \\
\hline P10 & 3.88 & 4.48 & -0.60 & \multirow[t]{5}{*}{-0.78} \\
\hline P11 & 3.52 & 4.51 & -0.99 & \\
\hline P12 & 3.84 & 4.48 & -0.64 & \\
\hline P13 & 3.70 & 4.42 & -0.72 & \\
\hline P14 & 3.49 & 4.43 & -0.94 & \\
\hline P15 & 2.75 & 4.42 & -1.67 & \multirow[t]{5}{*}{-1.11} \\
\hline P16 & 3.75 & 4.43 & -0.68 & \\
\hline P17 & 3.84 & 4.49 & -0.65 & \\
\hline P18 & 2.60 & 4.09 & -1.49 & \\
\hline P19 & 3.10 & 4.16 & -1.06 & \\
\hline P20 & 3.91 & 4.48 & -0.57 & \multirow[t]{6}{*}{-0.76} \\
\hline P21 & 2.93 & 4.28 & -1.35 & \\
\hline P22 & 3.96 & 4.49 & -0.53 & \\
\hline P23 & 3.91 & 4.57 & -0.66 & \\
\hline P24 & 3.79 & 4.51 & -0.72 & \\
\hline P25 & 3.85 & 4.48 & -0.63 & \\
\hline P26 & 3.28 & 4.28 & -1 & \multirow[t]{6}{*}{-0.86} \\
\hline P27 & 3.88 & 4.49 & -0.61 & \\
\hline P28 & 3.93 & 4.52 & -0.59 & \\
\hline P29 & 3.85 & 4.49 & -0.64 & \\
\hline P30 & 3.87 & 4.58 & -0.71 & \\
\hline P31 & 2.52 & 4.13 & -1.61 & \\
\hline
\end{tabular}

Based on Table 4 above, it was generally seen that all question items have a negative gap value. This means that the services provided to the KSJ members were still below the respondents' expectations. The biggest gap value was -1.67 in item P15 (Attractive appearance of the KSJ office and physical facilities). This means that the appearance of the office and supporting equipment of the KSJ was very much needed by the respondents, but in reality the KSJ has not been able to provide the appearance of the KSJ office in accordance with the respondents 'wishes and is still far from respondents' expectations.

Meanwhile, the smallest gap value was -0.47 , that was on item P5 (KSJ employees are polite and friendly). This means $\mathrm{KSJ}$ has employees whose attitude is quite good in providing services to the KSJ members.

\section{Importance Performance Analysis}

The next step was to make a Cartesian diagram divided into four quadrants with a certain priority scale according to the results of the questionnaire data processing regarding the 
satisfaction and expectation level of the KSJ members as shown in Figure 1.

Quadrant 1 is a top priority, where respondents feel that the items contained in this section are very important, but the management of the KSJ has not been able to fulfill it, so members of the KSJ were not satisfied with the performance of the KSJ. The item contained in this quadrant was only 1 (one) item, which was related to KSJ providing extensive products and services (P11). In this case, it can be explained that the KSJ products and services relied upon to date are retail transactions through shipsmart and murabahah product services (sale-purchase agreements) and Qardh (soft loans). As a sharia cooperative, the KSJ actually also has the opportunity to offer various other products and services such as ijarah (rent), wadi'ah (deposit) hawalah (takeover of receivables), (representatives), rahn (guarantees), kafalah (guarantees) and others. However, the above mentioned products and services have not yet been run by KSJ optimally and extensively. This is due to the fact that the most cooperative members are not familiar with sharia transaction products.

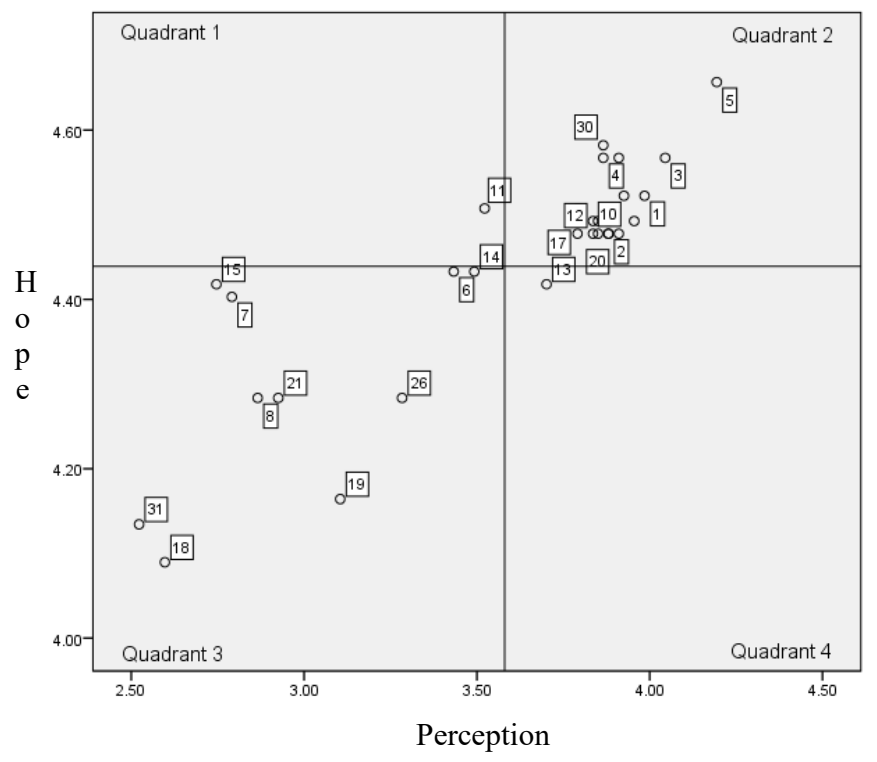

Fig. 1. IPA's Graphics of KSJ Service.

Quadrant 2 is a position where the respondent feels that the items contained in this section are important, and the KSJ has succeeded in fulfilling it well, so the item must be maintained and if necessary improved to be superior to the library. These items were: KSJ carries out Islamic principles and law (P1), There is no interest payment on types of financial services at KSJ (P2), KSJ applies Islamic product service provisions (P3), KSJ provides an opportunity to get an interest-free loan (P4), KSJ employees are polite and friendly (P5), An experienced and knowledgeable KSJ management team (P9), KSJ provides pleasant service (fast service time) (P10), KSJ provides security and guarantees in transactions (P12), KSJ provides fast and efficient transactions (P16), KSJ has clear operating hours (P17), Easily reachable location of KSJ (P20), KSJ maintains the confidentiality of member data (P22), KSJ management is convincing (P23), KSJ provides profitable products and services (P24), KSJ provides a low service tariff (P25), KSJ employees are willing to help members (P27), KSJ employees serve members in Islamic way (P28), KSJ provides loans with a favorable repayment period (P29), KSJ provides fast and efficient service (P30).

Quadrant 3 is a position where the respondent feels that the items contained in this section are less important and the KSJ has not been able to fulfill, so the respondent only behaved normally towards the item. The items in this quadrant were: KSJ provides financial advice/suggestions (P6), KSJ has a comfortable office interior and waiting room (P7), KSJ provides access to account information (P8), KSJ has integrated use of value added services (P14), Attractive appearance of KSJ offices and physical facilities (P15), KSJ provides reading material while members are waiting (P18), KSJ provides cash withdrawal services with privileges (P19), Providing adequate parking area (P21), KSJ has financial consultation provisions (P26), KSJ has available and sufficient branches (P31).

Quadrant 4 is a position where the items contained in this section are less important, but the respondent feels that the KSJ has been able to fulfill it. The items contained in this quadrant pertain to KSJ has an optimal service time (hours) (P13).

\section{CONCLUSIONS}

Based on the research result that has been done, some conclusions that can be drawn are as follows:

- In general, the whole question item has a negative gap value. The biggest gap value was -1.67 in item P15 (Attractive appearance of KSJ offices and physical facilities). Meanwhile, the smallest gap value was -0.47 for the item of P5 (KSJ employees are polite and friendly).

- There was one service attribute that need to be improved based on the Importance Performance Analysis method, which was in quadrant A or high priority quadrants that need to be corrected, that was attribute P11 (KSJ provides extensive products and services).

\section{ACKNOWLEDGMENT}

The researchers really thanked to all of KSJ members who were willing to participate in this research. We also do not forget to thank the whole KSJ employees who have helped the member to give their best service to meet the needs of customers and especially the members.

\section{REFERENCES}

[1] N. C. Ojiagu, C. Onugu and Uchenna, "Effects of Membership of Cooperative Organisations and Determinants on Farmer Members' Income in Rural Anambra State, Nigeria", International Journal Of Scientific \& Technology Research Vol. 4, Issue 08, pp. 28-35, August 2015.

[2] G. A. M. S. Agung, G. A. T. Kusuma, I. N. Suardhika and A. A. P. Agung, "Transparency of Cooperative Management Report as a Part of Service Quality in Improving Members' Satisfaction and Loyalty", 
[9] K. Khadka and S. Maharjan, "Customer Satisfaction and Customer Loyalty Case Trivsel Städtjänster (Trivsel siivouspalvelut)", Thesis, Centria University of Applied Sciences Business Management, Finland, 2017.

[3] M. Boland, An Introduction to Cooperation and Mutualism. Minnesota: University of Minnesota Libraries Publishing, 2017.

[4] K. Hidayat, Suharyono, S. Kumadji and Solimun, "The Effect of Members Participation on Business Self-Reliance and MembersWelfare (Study on Cooperative Corporation in East Java Indonesia)", International of Scientific Research JBM, Vol. 16, Issue 16, pp. 15-21, June 2014.

[5] A. J. Robb, J. H. Smith and J. T. Webb, "Cooperative Capital: What It Is and Why Our World Needs It", Journal of Cooperative Thought and Practice, Vol. 1, No. 1, pp. 7-37, Summer 2012.

[6] C. C. Huang, S. Zazale, R. Othman,N. A. Aris And S. M. M. Arif, "Influence of Cooperative Members' Participation and Gender on Performance", Journal of Southeast Asian Research, Vol. 2015, pp. 1-9, 2015.

[7] T. Sofiani, "Konstruksi Norma Hukum Koperasi Syariah Dalam Kerangka Sistem Hukum Koperasi Nasional”, Jurnal Hukum Islam (JHI), Vol. 12, pp. 135-151, December 2014

[8] D. Faolina, "Peran Koperasi Syariah Dalam Pembiayaan Usaha Kecil Dan Menengah (Studi Kasus Di KJKS BMT Insan Mandiri Sragen)", Publikasi Ilmiah, Program Studi Hukum, Surakarta : Universitas Muhammadiyah, 2017.

[10] Y. Yacob, J. K. Ali, C. J. Baptist, H. M. Nadzir and M. H. Morshidi, "How Far Members' Satisfaction Mediated Members' Loyalty? Investigating Credit Cooperative in Sarawak Borneo", Procedia - Social and Behavioral Sciences, 224, pp. 376-383, June 2016.

[11] R. Velmurugan and V. Gopinathan, V., "Customer's Satisfaction on Primary Agricultural Credit Co-Operative Societies", Journal of Advance Research in Dynamical \& Control Systems, Vol. 9, Issue 5, pp. 45-49, July 2017.

[12] R. N. Rachmadita and W. Arninputranto, "Analisis Kepuasan Pemustaka terhadap Kualitas Layanan Perpustakaan di Perguruan Tinggi Vokasi dengan Metode SERVQUAL dan Importance-Performace Analysis", Berkala Ilmu Perpustakaan dan Informasi, Vol. 14, No. 2, pp. 214-225, December 2018.

[13] S. B. D. Parani, A.M. Palampanga, Chalil and V. Fattah, "The Effect of Service Quality and Performance of Cooperative on Cooperative Image and Its Impact to the Satisfaction of Cooperative Member in the Central Sulawesi Province", European Journal of Business and Management, Vol. 9, No. 11, pp. 1-9, June 2016.

[14] J. J. Thoomkuzhy and M. E. John, "Service Quality Dimensions in Idukki District Co-Operative Bank", Journal of Management (JOM) Vol. 5, Issue 3, pp. 159-168, May-June 2018. 